\title{
EMPLACEMENT OF THE SNAP LAKE KIMBERLITE INTRUSION, NW TERRITORIES, ARCTIC CANADA
}

\author{
Gernon $\mathbf{T M}^{1 *}$, Ogilvie Harris $\mathbf{R C}^{2}$, Sparks RSJ $\mathbf{J}^{2}$, Field $\mathbf{M}^{3}$ \\ ${ }^{1}$ University of Southampton, Southampton, UK; ${ }^{2}$ University of Bristol, Bristol, UK; ${ }^{3}$ Diakim Consulting Ltd., Wells, UK \\ * presenting author: Thomas.Gernon@noc.soton.ac.uk
}

\begin{abstract}
The Cambrian (523 Ma) Snap Lake hypabyssal kimberlite intrusion, Northwest Territories, Canada, is a complex segmented diamond-bearing ore-body. Detailed geological investigations suggest that the kimberlite is a multi-phase intrusion with at least four different magmatic lithofacies. In particular, olivine-rich (phlogopite-poor) and olivinepoor (phlogopite-rich) varieties of hypabyssal kimberlite have been identified. Key observations are that olivine-rich lithofacies (ORK) has a strong tendency to be located where the intrusion is thickest and that there is a good correlation between intrusion thickness, olivine crystal size and crystal content. The olivine-poor lithofacies (OPK) tends to be most abundant where the intrusion is thinnest. The ORK groundmass is composed of phlogopite (3 - 20\%), apatite, $\mathrm{Cr}$ spinel with Fe-Ti rims and rutile. The OPK groundmass is composed of abundant phlogopite (30-60\%), monazite and rutile and sparse $\mathrm{Cr}$ spinel cores and remnants of $\mathrm{Fe}-\mathrm{Ti}$ rims. The ORK and OPK have a very different mineralogy and geochemistry indicating that they are contrasted magmas with different igneous histories, which have been mixed together in the intrusion. In addition, the ORK and OPK are characterised by different diamond abundances and size distributions. The geometry and distribution of lithofacies points to magmatic co-intrusion, and flow segregation driven by fundamental rheological differences between the ORK and OPK phases. We envisage that the low viscosity OPK magma acted as a lubricant for the highly viscous ORK magma. The presence of such low viscosity, crystal-poor magmas may explain how crystalladen kimberlite magmas $(>60$ vol.\%) are able to reach the surface and erupt in kimberlite diatremes. We also document the absence of crystal settling and the development of an unusual sub-vertical fabric of elongate olivine crystals, which are explained by rapid degassinginduced quench crystallisation of the magmas during and after intrusion. The igneous events have been followed by multiple stages of metasomatism, including (1) early
\end{abstract}

metasomatism, (2) serpentinization, and (3) alteration by acidic fluids derived from the surrounding granite. The Snap Lake intrusion provides important insights into the architecture and dynamics of magmatic plumbing systems at high crustal levels, particularly in settings where sheet intrusions feed into point-source diatreme-vent systems. The study also has implications for predicting diamond distributions at other kimberlite intrusions where different magmatic lithofacies can be identified.

\section{Introduction}

The Snap Lake Diamond Mine is located $\sim 220 \mathrm{~km}$ northeast of Yellowknife in the Northwest Territories of Arctic Canada. The Snap Lake Intrusion (SLI) is a complex segmented orebody comprising a series of sub-parallel sheets, dipping 5 to $30^{\circ}$ towards the northeast. In parts of the mine, the SLI is exposed as a single well-defined intrusion, ranging in thickness between 0.1 and $15 \mathrm{~m}$, but typically in the thickness range 3 to $5 \mathrm{~m}$.

We present data on intrusion thickness, lithofacies relationships, crystal size distributions, crystal fabric, crystal content and crystal concentration profiles. Snap Lake Mine presents excellent 3D exposures of a hypabyssal kimberlite intrusion. The intrusion contains abundant large olivine crystals whose distribution and fabric provide constraints on rheological properties and emplacement processes. Its study constrains the large- and small-scale processes of kimberlite emplacement in the upper crust and may shed light more generally on the magmatic plumbing of diatreme-vent systems. The relationship between olivine abundance and grain size with diamond grade and distribution at Snap Lake is assessed elsewhere (Field et al., 2009).

\section{Field observations}

The SLI is typically a moderate to highly porphyritic hypabyssal intrusion consisting of suspended altered olivine 
crystals in a fine-grained matrix. The rock is pervasively altered; fresh olivine has not yet been found and all olivine crystals are pseudomorphed by serpentine. Calcite and dolomite are present, both in the interstices between crystals and as lenticular veins, which commonly cut across original igneous textures and fabrics. Alteration varies in style; for example, olivine is commonly replaced by pale (low $\mathrm{Mg}$ ) serpentine and in some zones by dark (high $\mathrm{Mg}$ ) serpentine. The proportion of olivine crystals varies significantly throughout the intrusion. In places, the content of macrocrysts is $\geq 20 \%$ and here it is defined as olivine-rich. Where the crystal content is $<20 \%$, it is defined as olivinepoor. This threshold was chosen because samples show bimodality in crystal content and $20 \%$ is approximately the boundary between the two groups.

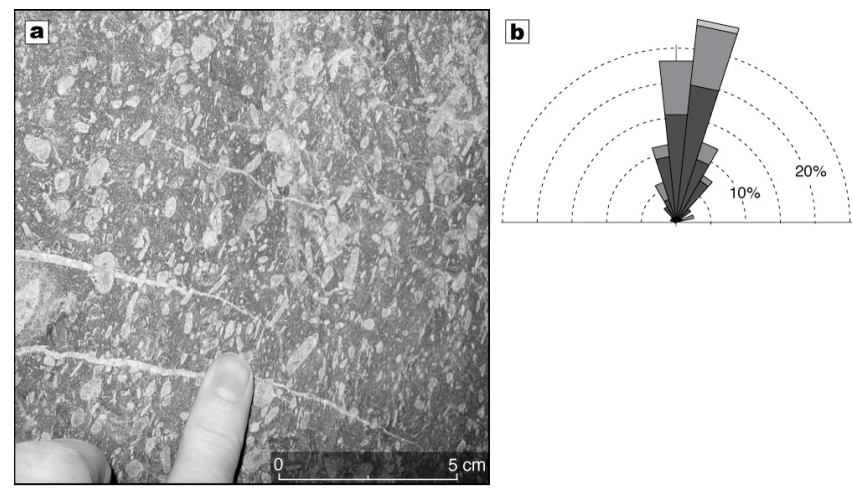

Fig. 1. Olivine-rich macrocrystic kimberlite (ORK), in which a strong subvertical fabric is discernible. (b) Rose plot shows the fabric defined by longaxis orientations of olivine crystals in the plane of the exposure.

\section{Olivine-rich hypabyssal kimberlite (ORK)}

The olivine-rich lithofacies typically has a massive appearance, and dominantly comprises fine to coarse olivine macrocrysts (20 to 75 area \%), olivine microcrysts (10 to 50 area $\%)$, very coarse macrocrysts $(\sim 5$ area $\%)$, and a range of country rock xenoliths (typically 2 to 10 area \%, locally $\geq 25$ area \%). Olivine macrocrysts are generally anhedral-to-subhedral and typically elongate (Fig. 1a), with length : width ratios ranging between $2: 1$ to $10: 1$. At an outcrop scale, a preferred sub-vertical alignment fabric of olivine long axes (i.e. perpendicular to the intrusion walls) is commonly seen (Fig. 1b). In thin section, serpentine both replaces olivine and is recognised in the interstices between crystals. Some pseudomorphed groundmass microcrysts may be after monticellite rather than olivine based on their equant shapes. Complex intergrowths of serpentine and apatite are observed. Secondary dolomite occurs in the interstices between crystals. Together with serpentinised olivine, groundmass components include phlogopite (3 to $20 \%$ ), apatite $(3$ to $10 \%)$, chrome spinel $(\sim 1 \%)$, rutile $(\sim$
$1 \%)$ and titanite $(<1 \%)$. Phlogopite and apatite are typically highly localised and occur in small (100 to $500 \mu \mathrm{m}$ diameter) accumulations. In general, the ORK contains relatively large $(0.1$ to $1 \mathrm{~mm})$ elongate phlogopite laths, commonly exhibiting decussate textures.

\section{Olivine-poor hypabyssal kimberlite (OPK)}

The olivine-poor kimberlite (OPK) lithofacies is characterised by a relatively low proportion of fine to medium olivine macrocrysts ( 5 to 20 area \%), a paucity of coarse olivine macrocrysts and mantle nodules $(<5$ area $\%)$, and a high abundance of phlogopite crystals (typically 30 to 60 area \%). Phlogopite is particularly abundant immediately adjacent to the country rock contact. In most cases, the distribution of crystals is heterogeneous, giving the rock a very patchy appearance. In the OPK, olivines occur mainly as small microcrysts, commonly separated by elongate phlogopite laths. The olivine grain boundaries are poorly discernible, constituting amorphous masses of serpentine. Phlogopite (Ti-rich and Ti-poor varieties) generally occurs as relatively large laths $(100$ to $750 \mu \mathrm{m})$ in the OPK. The phlogopite laths commonly contain inclusions of chromite, Ti-rich spinel (with atoll textures), rutile, and small serpentinised equigranular crystals; the latter are thought to be pseudomorphs after monticellite. Phlogopite crystals commonly exhibit random orientations, though towards the upper and lower contacts are strongly aligned parallel to the intrusion contact. The interstitial groundmass contains secondary serpentines (Mg-rich and Mg-poor) and dolomite.

Rare apatite in the OPK lithofacies typically occurs as small isolated grains $(\sim 20 \mu \mathrm{m})$ in contrast to the ORK lithofacies. Some domains of the crystal-poor lithofacies, particularly towards the intrusion margins, contain pervasive veins in which olivine is replaced by vermiform serpentine (antigorite), and an interstitial cement of serpentine, dolomite and altered phlogopite.

\section{Discussion}

The Snap Lake kimberlite is a discordant thin intrusion composed of various hypabyssal lithofacies. The two endmember lithofacies are petrologically and geochemically distinct (Ogilvie-Harris et al., 2009). Together, textural, mineralogical and geochemical differences point towards the two lithofacies representing different magmatic phases that have undergone different processes during ascent and emplacement. Magma batches with different characteristics have been observed in other kimberlite intrusions (e.g. Wesselton and Lethlakhane; Sparks et al., 2006, 2009). 


\section{0 $^{\text {th }}$ International Kimberlite Conference, Bangalore - 2012}
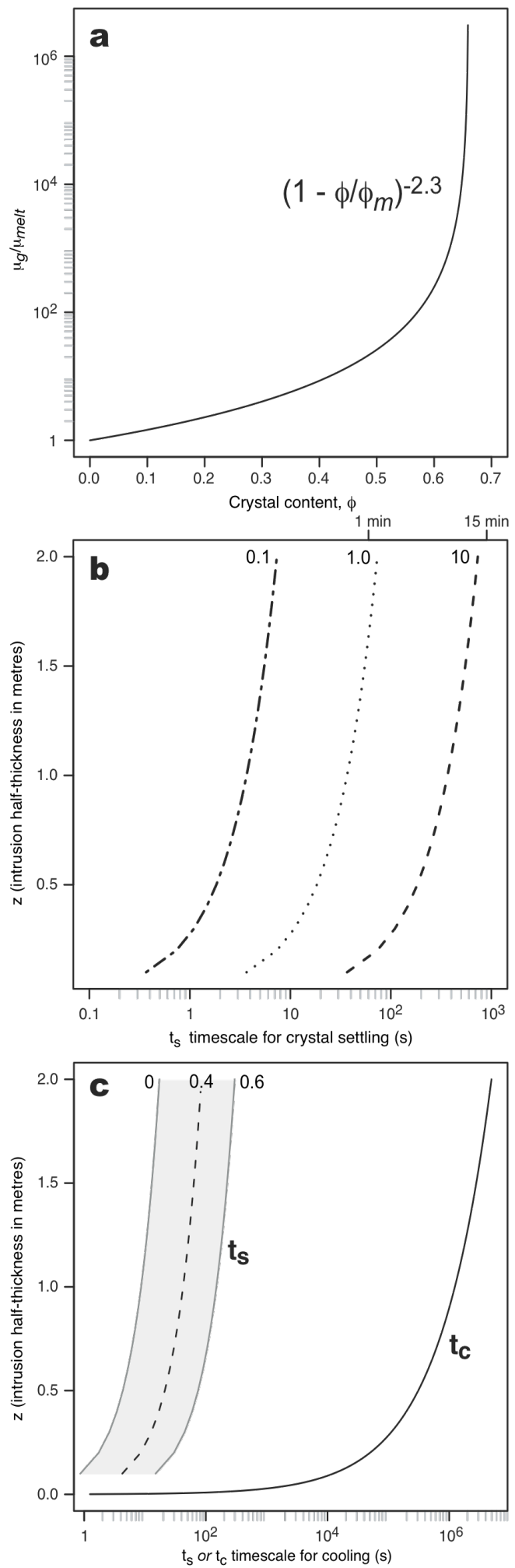

Fig. 2. (a) Ratio of groundmass viscosity $\left(\mu_{\mathrm{g}}\right)$ to melt viscosity $\left(\mu_{\text {melt }}\right)$ as a function of crystal content $(\varphi)$. (b) Timescale of crystal settling $\left(t_{s}\right)$ as a function of depth $(\mathrm{z})$ over a range of melt viscosities (values given are in Pa s), where $\varphi=0$. (c) Timescale of crystal settling (ts) as a function of depth for $\mu=0.1 \mathrm{~Pa}$ s at different crystal concentrations (shown).

\section{Importance of magma viscosity}

Crystal-laden magmas such as the ORK are known to exhibit complex rheological behaviour (Castruccio et al., 2010). As such, the major textural differences between OPK and ORK lithofacies imply markedly different rheological properties during magma transport. Relative to crystal-free magmas (i.e. melt), crystal-rich magmas can have much higher viscosities and can develop non-Newtonian rheologies (see Castruccio et al. , 2010). Figure 2a shows the variation of groundmass viscosity, $\mu_{\mathrm{g}}$ as a function of crystal content, $\varphi$. When the crystal content reaches about $60 \%$, large increases in yield strength and viscosity occur (Caricchi et al., 2007). For example, an increase in crystal content from 0 to 0.6 will increase the groundmass viscosity from 0.1 to $365 \mathrm{~Pa} \mathrm{~s}$.

\section{Absence of crystal settling and magma solidification}

A key feature in the Snap Lake intrusion is the general absence of size grading. In addition, large $(\leq 2 \mathrm{~m})$ locally derived country rock xenoliths are commonly observed to rest upon the upper contact of the ORK lithofacies at the base of the OPK, suggesting that the ORK had crystallised extensively before solidification of the OPK. Figure $2 b$ shows calculations on the timescales of crystal settling (for a $1 \mathrm{~cm}$ olivine crystal) as a function of distance and melt viscosity, which are then compared with the timescale for conductive cooling of the intrusion (Fig. 2c). A magma density $\left(\rho_{f}\right)$ of $2800 \mathrm{~kg} \mathrm{~m}^{-3}$ is assumed (Sparks et al., 2006) and the density of olivine $\left(\rho_{s}\right)$ is taken as $3300 \mathrm{~kg} \mathrm{~m}^{-3}$ (i.e. $\Delta \rho=500 \mathrm{~kg} \mathrm{~m}^{-3}$ ).

For large olivine macrocrysts settling through a mixture of melt and suspended small groundmass crystals, we choose a range of crystal contents $(\varphi=0.3-0.6)$ in the intrusion. Figure 2c shows the timescale for crystal settling as a function of depth in the intrusion for a melt viscosity of $\mu=$ $0.1 \mathrm{~Pa} \mathrm{~s}$. Hindered settling increases crystal settling times (Fig 2c), but these remain much less than the intrusion cooling time. To a first approximation, the Snap Lake intrusion would take 55 - 60 days to cool (Fig. 2c), given a representative dyke thickness of $4 \mathrm{~m}$ and thermal diffusivity of $8 \times 10^{-7} \mathrm{~m}^{2} \mathrm{~s}^{-1}$. The timescale for crystal settling (Fig. 2bc) is therefore substantially shorter $\left(10^{2-4}\right.$ times $)$ than that of conductive cooling of the intrusion for all reasonable geological conditions. In order for settling times to equal cooling times, and assuming a very high crystal content $(60 \%)$, the primary melt viscosity would have to be on the order of $10^{3}-10^{4} \mathrm{~Pa} \mathrm{~s}$. Although kimberlite melt compositions, temperatures and volatile contents are poorly constrained with much uncertainty (Sparks et al., 2009), the 


\section{$10^{\text {th }}$ International Kimberlite Conference, Bangalore - 2012}

evidence from field relationships, pyroclast textures and experiments on silica-poor melts is that the viscosities are very low. Sparks et al. (2006) summarised the evidence and concluded that they are likely less than $1 \mathrm{~Pa}$ s.

\section{Degassing-induced crystallisation}

There is a large discrepancy between crystal settling time, even at high crystal fractions, and cooling time (Fig. 2c) of the Snap Lake Intrusion. Even accounting for hindered settling through a crystal mush, olivine crystals should have settled easily and very rapidly if the groundmass were a melt. The observed absence of size grading, and the preservation of a strong sub-vertical fabric can be explained by pervasive internal groundmass crystallisation during and after emplacement; this would lead to highly elevated magma viscosities and abrupt solidification (Sparks et al., 2006). It is proposed that fabric generation coincided with quench crystallisation of decussate phlogopite crystals, observed in the interstices between large crystals and attributed to rapid degassing during emplacement.

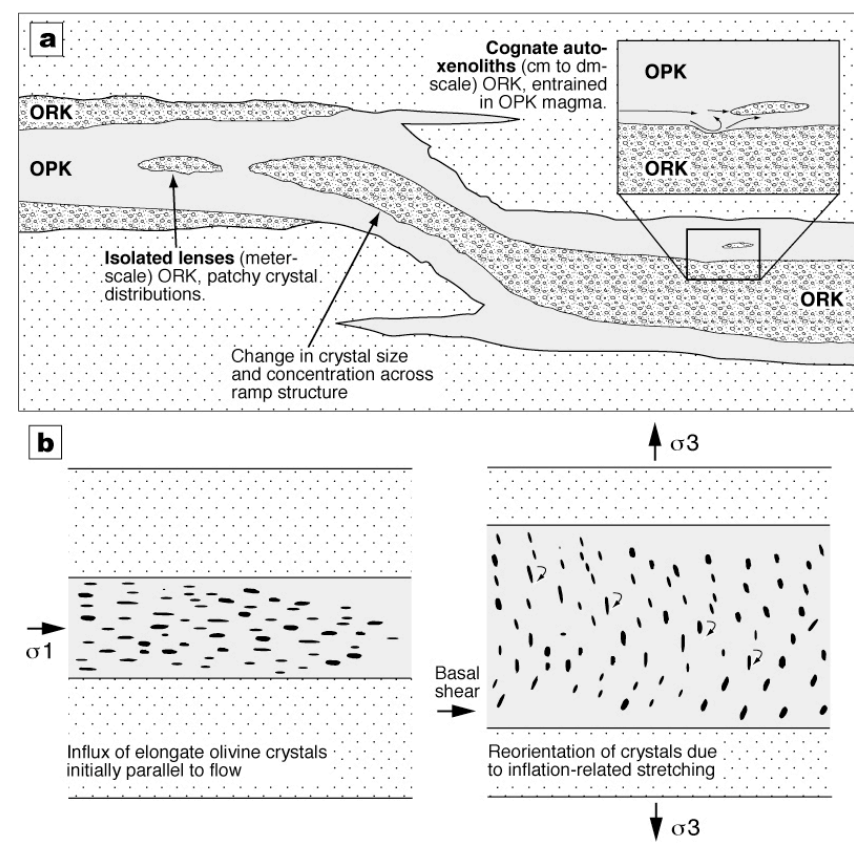

Fig. 3: (a) Schematic summary of structural complexities and lithofacies relationships within the Snap Lake Intrusion. Heterogeneities in crystal size and content occur over short distances in the intrusion. Inset: entrainment of cognate xenolith of ORK by relatively mobile OPK magma. (b) Schematic cartoons of fabric generation in the intrusion. When latestage ORK magma is injected in the centre of the intrusion, the parallel 'plates' pull apart to accommodate flowing magma. Consequently, elongate olivine crystals are rotated into more stable sub-vertical orientations.

\section{Conclusions}

Detailed geological mapping has demonstrated that the Snap Lake hypabyssal kimberlite intrusion is texturally heterogeneous, comprising olivine-rich and olivine-poor lithofacies. The lithofacies are petrologically distinct suggesting that the SLI is a multi-phase intrusion, emplaced by at least two magma batches. The variation in crystal content of the ORK and OPK indicates fundamental rheological differences between the magmas and different flow processes during transport and emplacement. The observed lack of grading and preservation of a sub-vertical fabric within the Snap Lake intrusion suggests that groundmass crystallisation occurred rapidly during and after emplacement. The emplacement processes outlined in this paper are potentially important in other types of subvolcanic sheet intrusions, particularly those associated with mafic and ultramafic diatreme-vent systems.

Note: for further information, please refer to:

Gernon, T.M., Field, M. \& Sparks, R.S.J., 2012. Geology of the Snap Lake kimberlite intrusion, NW Territories, Canada: Field observations and their interpretation. Journal of the Geological Society, 169 (1), doi: 10.1144/0016-76492011-056.

\section{References}

Caricchi, L., Burlini, L., Ulmer, P., Gerya, T., Vassalli, M. \& Papale, P. (2007). Non-Newtonian rheology of crystal-bearing magmas and implications for magma ascent dynamics. Earth and Planetary Science Letters 264 (3-4), 402-419.

Castruccio, A., Rust, A. C. \& Sparks, R. S. J. (2010). Rheology and flow of crystal-bearing lavas: Insights from analogue gravity currents. Earth and Planetary Science Letters 297, 471480, doi:10.1016/ j.eps1.2010.06.051.

Field, M., Gernon, T. M., Mock, A., Walters, A., Sparks, R. S. J. \& Jerram, D. A. (2009). Variations of olivine abundance and grain size in the Snap Lake kimberlite intrusion, Northwest Territories, Canada: A possible proxy for diamonds. Lithos $112 \mathrm{~S}, 23-35$.

Ogilvie-Harris, R., Sparks, R.S.J., Field, M. \& Gernon, T.M. (2009). The Geochemistry of the Snap Lake kimberlite dyke, NW Territories, Canada: Phlogopite and Spinel. Eos Trans. AGU, 90(22), Jt. Assem. Suppl., Abstract V33D-01.

Sparks, R. S. J., Baker, L., Brown, R. J., Field, M., Schumacher, J. Stripp, G. \& Walters, A. (2006). Dynamical constraints on kimberlite volcanism. Journal of Volcanology and Geothermal Research 155 (1-2), 18-48.

Sparks, R. S. J., Brooker, R. A., Field, M., Kavanagh, J., Schumacher, J. C., Walter, M. J., White, J. (2009). The nature of erupting kimberlite melts. Lithos 1125, 429-438. 